\title{
Proceedings of the
}

\section{CAMBRIDGE PHILOSOPHICAL SOCIETY}

\author{
VOLUME 32
}

PART 5

\section{CAMBRIDGE \\ UNIVERSITY PRESS \\ 1936 \\ Price Three Shillings and Sixpence Net}

February 1937 


\section{CAMBRIDGE PHILOSOPHICAL SOCIETY}

Founded 1819; Royal Charter 1832

\section{Session 1936-1937}

President: Dr F. W. ASTON.

Vice-Presidents : Prof. Sir J. BARCROFT, Dr C. G. DARWIN, Mr F. P. WHITE.

Secretaries: (Physical) Dr J. D. COCKCROFT, St John's College.

(Mathematical) Mr A. H. WILSON, Trinity College.

(Biological) Dr O. M. B. BULMAN, Sidney Sussex College.

The publications of the Society consist of the Proceedings and of the Biological Revieros. The publication of separate Transactions was suspended at the end of Volume XXIII.

Bookseller's orders should be sent to: The Manager, Cambridge University Press, Fetter Lane, London, E.C. 4.

For the purchase of early Parts of the Transactions and Proceedings application should be made to the Secretaries.

Felloros of the Society are particularly requested to inform the Secretaries of any change of postal address.

\section{PROCEEDINGS of the CAMBRIDGE PHILOSOPHICAL SOCIETY}

\section{Editorial Committee:}
W. V. D. HODGE, Editor
G. H. HARDY
J. D. COCKCROFT
M. H. A. NEWMAN
P. I. DEE
A. H. WILSON

1. Communications for the Proceedings should be sent to one of the above, or to The Philosophical Library, Cambridge.

2. Four parts of the Proceedings are issued during the year, viz. on January 31, April 30, July 30, October 31.

Papers should reach the Editor not later than February 13, May 13, August 13, November 13.

3. Papers occupying more than twenty pages of print can only very rarely be accepted.

4. Authors of papers are informed that the Illustrations and Diagrams are executed as far as possible by photographic "process" work; drawings should be on a large scale and on smooth white Bristol board in Indian ink.

Authors may receive, on request, fifty offprints of a paper in the Proceedings without charge. Additional eopies may be had by payment to the University Press. 